\title{
The Effect of Breast Care and Oxytocin Massage on Breast Milk Production in Postpartum Mothers in the Working Area of Pataruman Public Health Center III Banjar City
}

\author{
Mentari Ramadhini ${ }^{1}$, Citra Hadi Kurniati ${ }^{2}$ \\ ${ }^{1,2}$ Department of Health, Universitas Muhammadiyah Purwokerto, Indonesia
}

\begin{tabular}{l} 
ARTICLE INFO \\
\hline Article history: \\
DOI: \\
$\underline{10.30595 / \text { pshms.v2i.227 }}$
\end{tabular}

\begin{abstract}
The postpartum period refers to the first 42 days after childbirth. Breast milk contains the most appropriate and complete nutrient. Besides, it always adapts to the needs of the baby. There are several benefits of breast milk for babies the number of calories in breast milk can meet the needs of the baby, breast milk contains protective substances, and it strengthens the bond between a mother and her baby. Breast care stimulates prolactin, the hormone which helps milk production to facilitate breast milk. Oxytocin massage stimulates the posterior pituitary to release oxytocin, thus breast milk production is increased. This research aimed to determine the effect of breast care and oxytocin massage on breast milk production of postpartum mothers. In this research, the pre-experimental method was employed with a two-group pretest-posttest design. Most of the research respondents were 2035 years old, multiparas, and graduated from junior and senior high school. Before breast care and oxytocin massage were conducted to 27 (93\%) and 24 (86\%) postpartum mothers respectively, most of them had low breastmilk supply. While, after the treatments were given to 27 (93\%) postpartum mothers with breast care, and $24(86 \%)$ postpartum mothers with oxytocin massage, most of the respondents had better milk production. The Mann Whitney test held after breast care and oxytocin massage indicated that $\mathrm{p}$ value was $0.000(p<0,05)$ for both variables. There is an effect of breast care and oxytocin massage on breast milk production of postpartum mothers.
\end{abstract}

This work is licensed under a Creative Commons Attribution 4.0 International License.

Breast milk; Breast care; Oxytocin massage; Postpartum period

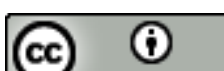

Corresponding Author:

Citra Hadi Kurniati,

Department of Health, Universitas Muhammadiyah Purwokerto,

Soepardjo Rustam Street KM. 7, Banyumas, Indonesia

Email: citrahadi85@gmail.com

\section{INTRODUCTION}

The postpartum period is the period starting from the birth of the placenta and the baby up to 6 weeks or 42 days. At this time is an important period in a mother's life where in the postpartum period a mother experiences various kinds of feelings, namely the feeling of happiness because of successfully having children, but there are times when feelings arise confused with new responsibilities so that a mother often experiences fatigue that can result in decreased production of breast milk. [1]

Problems faced by postpartum mothers who are breastfeeding generally occur in the first two weeks of the postpartum period. At this time, the supervision and attention of health workers, especially midwives, is needed so that the problem of breastfeeding can be addressed immediately, so as not to become a refiner or cause breastfeeding failure. [2]

The problem of maternal nifas related to breastfeeding still occurs in some areas that have not been achieved exclusively. Nationally, the coverage of infants getting exclusive breast milk in 2019 was $67.74 \%$. This figure has exceeded the 2019 Renstra target of 50\%. The highest percentage of exclusive breastfeeding coverage is in West Nusa Tenggara Province (86.26\%), while the lowest percentage is in West Papua 
Province (41.12\%) There are four provinces that have not reached the 2019 Renstra target, namely Gorontalo, Maluku, Papua, and West Papua. [3]

The puerperium is divided into 3 stages, namely early puerperium, puerperium intermedia and remote puerperium. Early puerperium is the period of recovery where the mother is allowed to walk. Puerperium intermedia is a complete recovery of external and internal genital organs which lasts 6-8 weeks. Remote puerperium is the time needed to recover and be perfectly healthy, especially for mothers during pregnancy or childbirth who have complications. [4]

The purpose of the postpartum period is to maintain the health of the mother and her baby, both physically and psychologically, carry out comprehensive screening, detect problems, treat, or refer if complications occur to the mother or baby and provide health education about personal health care, nutrition, family planning, breastfeeding, or providing immunizations for babies and caring for healthy babies. [4]

Postpartum technical programs and policies, namely visit $1(6-8$ hours $)$ where the midwife ensures that the mother gives breast milk in the early days of becoming a mother and teaches how to strengthen the relationship between mother and newborn. Visit 2 (6 days postpartum), which is to make sure the mother is breastfeeding well and there are no signs of complications. The 3 rd visit ( 2 weeks postpartum) is to make sure the mother is breastfeeding well and there are no signs of complications and Visit 3 (6 weeks postpartum) is to ask the mother about the complications she is experiencing or her baby. [4]

The role and responsibility of midwives in the postpartum period is that the midwife is able to provide health education and counseling to clients about overcoming health problems, especially those related to maternal and child health. The care provided by midwives provides consulting services, even though they are well prepared and plus appropriate postpartum services, breastfeeding problems often arise that need to be addressed so that lactation can be maintained. [4]

Breast milk is very important for babies because breast milk is the best food for babies at the beginning of their life. Breast milk is proven to have advantages that cannot be replaced by any food and drink because breast milk contains the most appropriate, complete and always adjusted nutrients to the needs of the baby at all times. [5]

Breast milk is the best food for babies. For this reason, breast milk must be given to infants for at least 6 months and can be continued for up to 2 years. There is not a single study that rejects the goodness and benefits of breast milk containing substances that are very beneficial for babies, both substances for nutrition and protection. [4] Physiologically, the formation of breast milk is divided into 2 reflexes, namely the prolactin reflex and the letdown reflex.

For the stages of breastfeeding, it is divided into 3, namely colostrum that appears on the first to third days, known as a dilute golden liquid that is yellow in color or can also be clear and more like blood than milk, because it contains living cells such as white blood cells that can kill germs, therefore colostrum should be given to the baby. Transitional milk is milk that comes out after colostrum until before it becomes mature or mature breast milk appears on the fourth to tenth day. Boiled milk appears after the tenth day and has a relatively constant composition. [4]

The benefits of breast milk for infants are that it has a composition that is in accordance with the needs of the baby being born, the number of calories contained in breast milk can meet the needs of infants up to the age of 6 months and breast milk contains protective substances or antibodies that protect against disease. The benefits of breastfeeding for mothers include preventing postpartum bleeding and accelerating uterine involution. The benefits of breastfeeding for families are that it is easy to give and saves costs. While the benefits of breastfeeding for the state are reducing child morbidity and mortality, reducing subsidies for hospitals and reducing foreign exchange for buying formula milk. [4]

The problems of mothers in breastfeeding are lack of information, inverted nipples, swollen breasts, sore nipples, blocked milk ducts, inflammation of the breasts, breast abscesses, mothers after cesarean section, mothers with diseases and breastfeeding mothers who are pregnant again. [6]

Signs that the baby is getting enough breast milk, namely the baby suckles strongly and then falls asleep at least 8-12 times in 24 hours, the breasts will feel softer than before, defecate 2-5 times and urination 6-8 times, the baby has ideal weight and TB, immune system improved and good motor development. Breastfeeding time on average 10-12 times every 24 hours.

The volume of breast milk during breastfeeding at birth is up to $5 \mathrm{ml} 3-8$ feedings, in 24 hours 7 $123 \mathrm{ml} /$ day in $5-10$ feedings, between $2-6$ days i.e. $395-868 \mathrm{ml} /$ day in $6-18$ feedings. Efforts to increase breast milk are to let the baby and mother together, teach how to care for the breast and massage oxytocin, help mothers at the beginning of breastfeeding, give breast milk to babies as often as possible, and only give colostrum and breast milk and avoid "pacifier pacifiers". [7]

Factors that affect the inhibition of the breastfeeding process are the baby factor and the mother factor. Factors in the mother include, lack or misinformation, flat or sunset nipples, nutrition, nipple pain, nipple blisters, swollen breasts, mastitis or breast abscess (Setiowati, 2017). Factors that can affect the 
smooth production and expenditure of breast milk are breast care, oxytocin massage, frequency of breastfeeding, parity, stress, maternal disease or health, cigarette or alcohol consumption, contraceptive pills, and nutritional intake. [1]

Breast care is a stimulation that can be given to stimulate milk production. Breast care is a way of providing stimulation to the breast muscles to facilitate breast milk which consists of cleaning and stimulation of the nipples, breast massage and breast compresses. [8]

The purpose of breast care includes improving blood circulation and preventing blockage of the milk ducts so as to facilitate the release of breast milk, keeping the breasts clean and well cared for (nipples) because when breastfeeding the mother's breast will be in direct contact with the baby's mouth, avoiding sore and infected nipples and breast care. maintain the beauty of the shape of the breast. [4]

Breast care during the puerperium should start as early as possible. 1-2 days after the baby is born and be done 2 times a day before bathing. The principle of breast care is to keep the breasts clean and dry, especially the nipples, using a bra that supports and does not pressurize and breastfeeding is still done by prioritizing the nipples that are not blistered. [4]

In addition to breast care that can stimulate milk production, there is also a massage method that can stimulate the hormone oxytocin which is useful for facilitating and increasing breast milk production. Oxytocin massage is an act of spinal massage starting from the 5th - 6th nerves to the scapula which will accelerate the work of the parasympathetic nerves to convey commands to the back of the brain so that oxytocin comes out. [9]

The benefits of oxytocin massage are accelerating wound healing from placental implantation, preventinghemorrhage postpartum, accelerating the process of uterine involution, increasing breast milk production, increasing comfort in breastfeeding mothers, improving psychological relationships between mothers and families.[9]

The physiological effect of oxytocin massage is to stimulate uterine smooth muscle contractions both during labor and after delivery so that it can accelerate the process of uterine involution. Breast milk production is strongly influenced by the psychological condition of breastfeeding mothers. When breastfeeding mothers feel comfortable and relaxed, the release of oxytocin can take place well. There are points that can facilitate breastfeeding, including three points on the breast, namely the point above the nipple, the point right on the nipple and the point below the nipple. And a point on the back that is in line with the bust. Oxytocin stimulating massage for nursing mothers serves to stimulate the oxytocin hormone in order to facilitate breastfeeding and increase maternal comfort. Oxytocin massage is done 2 times a day for approximately 2-3 minutes in the afternoon and evening for 7 consecutive days. The effect of oxytocin massage itself can be seen in the reaction after 6-12 hours of massage. [1]

The initial study was conducted at Pataruman III Health Center in Banjar City in 2020 there was a problem in mother nifas in breastfeeding. The problem faced by postpartum mothers is breast milk comes out with small amounts, breast milk that does not come out so that the mother does not breastfeed and choose formula and mothers who do not know breast care and oxytocin massage. Breast milk coverage in Pataruman III Health Center banjar city reaches 58\%. This figure has exceeded renstra's target of 50\%. Although the coverage of breast milk in Pataruman III Health Center in Banjar City has exceeded Renstra's target, there are still mothers who have problems in breastfeeding and mothers who do not know about breast care and oxytocin massage. In connection with these conditions and problems, researchers are interested in conducting research entitled "The Effect of Breast Care and Oxytocin Massage on the Smooth Production of Breast Milk in Mrs. Nifas in the Working Area of Pataruman III Health Center in Banjar City".

\section{RESEARCH METHOD}

The research used in this study was pre-experimental with a two-group pretest-posttest design. This research was conducted in the working area of Pataruman III Public Health Center, Banjar City, West Java. The population in this study were mothers who gave birth in April - May 2021 in the Work Area of the Pataruman III Health Center, Banjar City. The sample is part of the number and characteristics possessed by the population. [10] The sampling method in this research is total sampling. Total sampling is atechnique when all members of the population are used as samples. [11] The research instrument with the variable breast care and oxytocin massage is the standard operating procedure (SOP) and for the research instrument on the variable milk production expenditure is the observation sheet and the syringe with units of cc. The data analysis technique consists of two analyzes, namely univariate analysis and bivariate analysis. The univariate analysis aims to explain or describe the characteristics of each research variable using the following formula.

As for the bivariate analysis in this study, it was used to determine the effect after being given breast care treatment and oxytocin massage on milk production. Aftercarried out, it was the Normality Test was found that the data were not normally distributed so that this study used the Mann Whitney which is a 
Testnon-parametric, testthis test was conducted to determine the difference before and after being given treatment in the two groups. Research license research ethics research at the health research ethics commission of Muhammadiyah Purwokerto University with registration number KEPK/ UMP/72/ IV/2021 research ethics in this study are that researchers must respect the freedom or independence of respondents in making decisions, researchers apply the principle of fairness in obtaining the risks and benefits of research, and have the opportunity to participate and be treated fairly and equally in research, researchers maximize benefits and minimize losses, and Researchers must prevent accidents or things that are not expected in the study, either physically or psychologically for participants. [12]

\section{RESULT AND DISCUSSIONS}

1. Characteristics of Respondents

Table 1. Frequency Distribution of Age, Education, and Parity of Postpartum Mothers in the Work Area of Pataruman III Health Center Banjar City

\begin{tabular}{|c|c|c|c|c|c|}
\hline \multirow[b]{2}{*}{ No } & \multirow[b]{2}{*}{ Characteristics of } & \multicolumn{2}{|c|}{ Breast Care } & \multicolumn{2}{|c|}{ Oxytocin Massage } \\
\hline & & $\begin{array}{l}\text { Frequency } \\
\text { (person) }\end{array}$ & $\begin{array}{l}\text { Present } \\
(\%)\end{array}$ & $\begin{array}{l}\text { Frequency } \\
\text { (person) }\end{array}$ & $\begin{array}{l}\text { Present } \\
(\%)\end{array}$ \\
\hline & Age & & & & \\
\hline 1 & $<20$ years & 1 & $3 \%$ & 2 & $7 \%$ \\
\hline 2 & $20-35$ years & 21 & $72 \%$ & 23 & $82 \%$ \\
\hline \multirow[t]{3}{*}{3} & $>35$ years & 7 & $25 \%$ & 3 & $11 \%$ \\
\hline & Total & 29 & $100 \%$ & 28 & $100 \%$ \\
\hline & Parity & & & & \\
\hline 1 & Primipara & 10 & $34 \%$ & 9 & $32 \%$ \\
\hline \multirow[t]{3}{*}{2} & Multipara & 19 & $66 \%$ & 19 & $68 \%$ \\
\hline & Total & 29 & $100 \%$ & 28 & $100 \%$ \\
\hline & Education & & & & \\
\hline 1 & Elementary School & 2 & $24 \%$ & 7 & $25 \%$ \\
\hline 2 & $\begin{array}{ll}\text { Junior } & \text { High } \\
\text { School } & \end{array}$ & 9 & $31 \%$ & 9 & $32 \%$ \\
\hline 3 & $\begin{array}{l}\text { Senior } \quad \text { Hight } \\
\text { School }\end{array}$ & 13 & $45 \%$ & 7 & $25 \%$ \\
\hline \multirow[t]{2}{*}{4} & Undergraduate & - & - & 5 & $18 \%$ \\
\hline & Total & 29 & $100 \%$ & 28 & $100 \%$ \\
\hline
\end{tabular}

Source: Primary Data 2021

In table 1 it is known that of the 29 respondents in the breast care group mostly aged 20-35 years, as many as $21(72 \%)$ respondents, while for age <20 years, as many as 1 ( $3 \%$ ) of respondents and age $>35$ years as many as $7(25 \%)$ respondents. In the oxytocin massage group, most of them were aged 20-35 years, as many as $23(82 \%)$ respondents, while for age $<20$ years, there were $2(7 \%)$ respondents and aged $>35$ years, namely $3(11 \%)$ respondents.

For parity characteristics, in the breast care group, most were multiparas, as many as $19(66 \%)$ respondents, while for primiparas as many as 10 (34\%) respondents and in the oxytocin massage group most were also multiparas, namely $19(68 \%)$ respondents while for primiparas as many as $9(32 \%)$ respondents.

For educational characteristics, in the breast care group, most of the respondents were senior high school as many as $13(45 \%)$ respondents, while elementary school were 7 (24\%) respondents, junior high school were $9(31 \%)$ respondents and in the oxytocin massage group most of the respondents were There are $9(32 \%)$ junior high school respondents, 7 (25\%) elementary school respondents, 7 (25\%) senior high school respondents and $5(18 \%)$ undergraduates respondents.

2. Univariate Analysis

Table 2. Distribution of Expenditure of Breast Milk Production in Postpartum Mothers before and after Breast Care in the Work Area of Pataruman III Public Health Center Banjar City

\begin{tabular}{llll}
\hline Variable & $\begin{array}{l}\text { Breast Milk } \\
\text { Production }\end{array}$ & Total & Percentage of \\
\hline Breast & Current Before & 2 & $7 \%$ \\
\hline
\end{tabular}




\begin{tabular}{llll}
\hline Care & $\begin{array}{l}\text { Non-current } \\
\text { Before }\end{array}$ & 27 & $93 \%$ \\
\hline Total & & 29 & $100 \%$ \\
\hline Breast & Current After & 27 & $93 \%$ \\
\cline { 2 - 4 } Care & $\begin{array}{l}\text { Non-current } \\
\text { After }\end{array}$ & 2 & $7 \%$ \\
\hline Total & & 29 & $100 \%$ \\
\hline
\end{tabular}

Source: Primary Data 2021

Based on table 2 above shows that milk production in postpartum mothers before breast care is mostly in the non-current category as many as 27 (93\%) respondents and $2(7 \%)$ respondent's milk production is smooth. While in postpartum mothers after breast care, most of them were in the current category as many as $27(93 \%)$ respondents and $2(7 \%)$ respondents their milk production was not smooth.

Table 3. Distribution of Production Expenses milk to Mother Postpartum before and after massage Oxytocin in Puskesmas Pataruman III Banjar

\begin{tabular}{lccc}
\hline Variable & $\begin{array}{c}\text { milk } \\
\text { production }\end{array}$ & Total & Percentage of \\
\hline $\begin{array}{l}\text { massage } \\
\text { Oxytocin }\end{array}$ & Current Before & 4 & $14 \%$ \\
\cline { 2 - 4 } & $\begin{array}{c}\text { Non-current } \\
\text { Before }\end{array}$ & 24 & $86 \%$ \\
\hline Total & Current After & 28 & $100 \%$ \\
\hline $\begin{array}{c}\text { massage } \\
\text { Oxytocin }\end{array}$ & $\begin{array}{c}\text { Non-current } \\
\text { After }\end{array}$ & 3 & $11 \%$ \\
\hline Total & & 28 & $100 \%$ \\
\hline
\end{tabular}

Source: Primary Data 2021

Based on table III above shows that milk production in postpartum mothers before oxytocin massage is mostly in the non-fluent category as many as $24(86 \%)$ and $4(14 \%)$ production respondents The milk is smooth. Meanwhile, after oxytocin massage on postpartum mothers showed that milk production in postpartum mothers after oxytocin massage was mostly in the smooth category as many as 25 (89\%) respondents and $3(11 \%)$ respondents their milk production was not smooth.

3. Bivariate analysis

Table 4. Normality test of data was carried out using Shapiro - Wilk test

\begin{tabular}{lll}
\hline Variable & $\boldsymbol{P}$-value & Description \\
\hline Before Breast Care & 0,000 & Abnormal \\
\hline After Breast Care & 0,001 & Abnormal \\
\hline $\begin{array}{l}\text { Before massage } \\
\text { Oxytocin }\end{array}$ & 0,001 & Abnormal \\
\hline $\begin{array}{l}\text { After massage } \\
\text { Oxytocin }\end{array}$ & & \\
\hline $\begin{array}{l}\text { Source: Primary Data } 2021 \\
\end{array}$ &
\end{tabular}

Based on table 4 showed that the Normality Test with Shapiro - Wilk on the variables before breast treatment $p$ - value 0.000 then after breast treatment $p$ - value 0.001 , and before oxytocin massage $p$ - value 0.001 and after oxytocin massage $\mathrm{p}$ - value 0.014 . This shows that the p-value is smaller than 0.05 so it can be concluded that the four variables are not normally distributed so that the researcher will use the Mann Whitney Test. 
Table 5. Effect of Breast Care and Oxytocin Massage on Expenditure of Breast Milk Production in Postpartum Mothers in the Work Area of Pataruman III Health Center Banjar City

\begin{tabular}{lllll}
\hline No & $\begin{array}{l}\text { Milk After } \\
\text { Production }\end{array}$ & $\begin{array}{l}\text { Mean } \\
\text { Before }\end{array}$ & $\begin{array}{l}\text { Mean } \\
\text { After }\end{array}$ & Sig (2-tailed) \\
\hline 1 & Breast Care & 15,26 & 43,74 & 0,000 \\
\hline 2 & $\begin{array}{l}\text { Massage } \\
\text { Oxytocin }\end{array}$ & 15,00 & 42,00 & 0,000 \\
\multicolumn{5}{l}{ Source: Primary Data 2021}
\end{tabular}

Based on table 5 shows that the results of data analysis with the Mann Withney Test in table 5 above indicate that the average milk production in the breast care group is smoother than without breast care, which is $43.74>15.26$ and Sig $(2$ - tailed) $0.000<0.05$, which means that there is an effect of breast care on the production of breast milk in postpartum mothers.

For the results of data analysis using the Mann Withney test in table 5 above, it shows that the average milk production in the oxytocin massage group is $42.00>15.00$ and Sig $(2-$ tailed) $0.000<0.05$, which means that there is an effect of oxytocin massage on production of breast milk in postpartum mothers.

From the results of research that has been carried out in the Pataruman III Health Center Work Area, Banjar City in April - May 2021 the number of respondents in this study were 57 postpartum mothers, consisting of 29 postpartum mothers in the breast care group and 28 postpartum mothers in the oxytocin massage group.

1. Characteristics of Respondents

a. Characteristics of Respondents by Age

Based on the results of the study, most postpartum mothers aged 20-35 years in the breast care group showed $21(82 \%)$ postpartum mothers and the oxytocin massage group showed 23 (82\%) postpartum mothers, in the Work Area of Pataruman III Health Center Banjar City. Most of this research is aged 20-35 years, where at the age of 20-35 years is a healthy period for a woman to reproduce and have healthy body functions. According to Pranajaya's research (2013) says that the healthy reproductive age is the age of 20-35 years where this age is the best period for pregnancy, childbirth and breastfeeding.

b. Characteristics of Respondents based Parity

On Based on the results of the study, most of the postpartum mothers in the breast care group showed $19(66 \%)$ multiparous postpartum women and the oxytocin massage group showed 19 (68\%) multiparous postpartum women in the Pataruman III Health Center Work Area Banjar City. The results of this study indicate that most of the parity multiparas where postpartum mothers with multiparity parity already have experience in breastfeeding, physiologically the alveoli have previously been used or produce breast milk and postpartum mothers with multiparity parity already have readiness, especially in breastfeeding. According to Wijayanti's research (2016), mothers who give birth to their second child and so on have more milk production than the birth of their first child.

c. Characteristics of Respondents basedEducation Level

On Based on the results of the breast care group research, most of the education level was SMA/K, namely $13(45 \%)$ postpartum mothers and in the oxytocin massage group, the majority of junior high school education levels were 9 (32\%) postpartum mothers in the Public Health Center Work Area. Pataruman III Banjar City. The results of this study indicate that education for postpartum mothers has varied levels of education and postpartum mothers can receive health information, especially health about breasts. According to research Jannah et al. (2018) said that one's education cannot be used as a guideline that one will be successful in the breastfeeding process. However, correct and accepted information about the previous breastfeeding process determines the success of the breastfeeding process.

2. Univariate Analysis

a. Distribution Expenses milk production before and after Breast Care at Capital Ruling in Puskesmas Pataruman III Banjar

On the research that has been done in puerperal women shows that prior to the treatment of breast, there are 27 (93\%) of mothers postpartum outgoings milk noncurrent based on the measurement results of breast milk expenditure using a formula to determine the percentage achieved. Then postpartum mothers were given breast care treatment for \pm 20 minutes, indicating that after breast care there were $27(93 \%)$ postpartum mothers experienced smooth milk production based on the results of measuring breast milk expenditure using a formula to determine the percentage achieved. So it can be concluded in this study that breast care can improve the smooth production of breast milk in postpartum mothers properly. According to

Proceeding homepage: https://conferenceproceedings.ump.ac.id/index.php/pshms/issue/view/10 
research Yuniarti (2018) said in her research that breast care interventions were able to give the effect of increasing the volume of breast milk in postpartum mothers.

The prolactin hormone produced from breast care is what helps produce milk so that the mother's breasts will be full and stimulate milk production. Breast care is a stimulation that can be given to stimulate milk production. This is in line with the theory of Indrayani \& Ph. (2019) that breast care is a way of providing stimulation to the breast muscles to facilitate breastfeeding which consists of cleansing, nipple stimulation, breast massage and breast compresses.

According to Yuniarti's research (2018), physiologically from the third day to the sixth day after giving birth, breastfeeding is usually produced, the breasts become very full. Physiologically, breast milk will come out but the process of breastfeeding must be given since the baby is born because breast milk has benefits for babies where the first to second day of breastfeeding is called colostrum. According to Astutik theory (2015) says that colostrum is very good for babies because it contains living cells such as white blood cells that can kill germs, therefore colostrum should be given to babies. In addition, the composition of breast milk according to the needs of the baby is not in drinks or formula milk, breast milk contains protective substances, breast milk can support the development of vision, breast milk can strengthen the bond between mother and baby and breast milk is given for at least 6 months causing the baby's psychomotor development to be faster. In addition, if the baby is breastfed from birth it will prevent stunting. Early initiation of breastfeeding (IMD), failure of exclusive breastfeeding (ASI), and early weaning are factors that cause stunting. [13] (Kurniati, CH, 2020).

When the baby is late to start breastfeeding on the first day and both mothers will give formula milk, the baby will get used to being given formula milk, the impact that often occurs is that the baby will be lazy to breastfeed because the milk produced by the mother's breast is little because the baby is accustomed to the portion of formula milk from birth or the baby is lazy shrink because the amount of breast milk is small, besides that the mother is not used to stimulation. Babies have been given formula milk with babies which will indirectly affect the frequency of feeding the baby where the frequency of feeding the baby is reduced so that the work of the prolactin hormone in producing and secreting milk decreases which causes breast milk to decrease and become not smooth. [14] (Wijayanti, 2016).

Therefore breast care in this study is very important because breast care will help stimulate milk production. This is in line with the research of Jannah et al. (2018) which concludes that breast care is a necessity for mothers who have just given birth and a very important action to facilitate the release of breast milk by stimulating the breasts will affect the pituitary to secrete morehormones progesterone and estrogen than usual, and stimulate the mammary glands through massage.

b. Distribution Expenses milk production before and after the massage Oxytocin Mother Ruling in the Work

Area of the Puskesmas Pataruman III Banjar

Based on the research that has been done in puerperal women shows that prior to the massage oxytocin, there were $24(86 \%)$ of mothers postpartum outgoings milk noncurrent based on the measurement results of breast milk expenditure using a formula to determine the percentage achieved. Then postpartum mothers were given oxytocin massage treatment for \pm 20 minutes, indicating that after the oxytocin massage there were $25(89 \%)$ postpartum mothers experienced smooth milk production based on the results of measuring breast milk expenditure using a formula to determine the percentage achieved. So it can be concluded that oxytocin massage can improve the smooth production of breast milk in postpartum mothers well. There is an effect before and after oxytocin massage treatment on the production of breast milk in postpartum mothers. [15]

When the postpartum mother is given an oxytocin massage, it will make the mother feel comfortable so that it will produce the hormone oxytocin. This oxytocin hormone will increase the production of breast milk. This hormone is known as the love hormone. Love will be channeled to the baby through the smooth production of breast milk so that the baby also gets comfort because the milk produced can meet their needs. Oxytocin massage is an act of spinal massage starting from the 5th - 6th nerves to the scapula which will accelerate the work of the parasympathetic nerves to convey commands to the back of the brain so that oxytocin comes out. [16]

c. The Effect of Expenditure on Breast Milk Production before and after Breast Care and Oxytocin Massage

on Postpartum Mothers in the Work Area of the Pataruman III Public Health Center Banjar City

Results Mann Withney Test on breast care data are $p$ - value 0.000 with a mean before breast care treatment is 15.26 and after being given treatment breast care is 43.74. This shows that $p-v a l u e<0.05$ then $_{\mathrm{Ho}}$ is accepted. Thus there is an effect of milk production before and after breast care. While the results of the Mann Withney test on oxytocin massage data is $p$ - value 0.000 with a mean before oxytocin massage treatment is 15.00 and after oxytocin massage treatment is 42.00 . This shows that $p$ value $<0.05$ then $\mathrm{Ho}_{\mathrm{Ho}}$ accepted. Thus there is an effect of milk production before and after oxytocin massage. The results of this study indicate that breast care and oxytocin massage have an effect on milk production. There is a

Proceeding homepage: https://conferenceproceedings.ump.ac.id/index.php/pshms/issue/view/10 
relationship between before and after oxytocin massage and breast care on milk production in postpartum mothers. [16]

From the two treatments, it is necessary to stimulate the prolactin hormone by doing breast care and the oxytocin hormone by oxytocin massage. Both treatments can both facilitate and increase milk production. Additional measures such as breast care and oxytocin massage are needed to increase milk production. These two actions also help mothers participate in the exclusive breastfeeding program for infants aged 0-6 months. [1]

Disrupted milk production can be treated pharmacologically and non-pharmacologically. The use of pharmacological and non-pharmacological therapies will help postpartum mothers in expressing breast milk. However, with non-pharmacological therapy, postpartum mothers can save expenses for visits to medical personnel and the purchase of drugs to express breast milk. In addition, postpartum mothers will give formula milk because breast milk does not come out, this in addition will increase the expenditure of postpartum mothers, it will also have an impact on the baby where the baby will be lazy to suck because he is used to being given breast milk with a stable volume of milk output without any effort to expel it.

Another impact of late breastfeeding the baby will be the wrong nipple so that when it is fed the baby will refuse. Therefore, breast care and oxytocin massage will help postpartum mothers stimulate the hormone prolactin and the hormone oxytocin which affect the production of breast milk. There is an effect after breast care and oxytocin massage on milk production in postpartum mothers. [8]

\section{CONSLUSION}

a. Characteristics based on age, most of them aged 20-35 years, characteristics based on parity most postpartum mothers with multiparity parity and characteristics based on education having varied education, namely elementary, junior high, high school and bachelor's.

b. There is an effect before and after breast care on breast milk production in postpartum mothers with a $p$ value of 0.000 , which means that the $p$-value $<0.05$, then $\mathrm{H}_{\mathrm{o}}$ is accepted.

c. There is an effect before and after oxytocin massage on breast milk production in postpartum mothers with a $p$-value of 0.000 indicating that $p$-value $<0.05$ then $\mathrm{H}_{\mathrm{o}}$ is accepted.

\section{Acknowledgements}

The authors would like to thank Allah SWT who has given health and convenience in carrying out this research, both parents and all comrades in arms who have helped from beginning to end.

\section{REFERENCES}

[1] Astutik, "Buku Ajar Asuhan Masa Nifas dan Menyusui," Jakarta: CV: Trans Info Media, Cetakan Pertama, 2015.

[2] Dewi \& Sunarsi, "Asuhan Kebidanan pada Ibu Nifas, " Jakarta: Salemba Medika, 2013.

[3] Heryana, "Etika Penelitian : Bahan Ajar Mata Kuliah Metodologi Penelitian Kuantitatif," Universitas Esa Unggul, 2020.

[4] Indrayani \& Ph, "Pengaruh Pijat Oksitosin dan Pijat Payudara terhadap Produksi ASI Ibu Postpartum di RB Citra Lestari Kecamatan Bojonggede Kota Bogor Tahun 2018," Journal for Quality in Women's Health, 2019.

[5] Jannah, dkk, "Perbedaan Efek Pijat Oksitosin dan Perawatan Payudara terhadap Produksi ASI pada Ibu Nifas di Kota Pekalongan," Jurnal Kebidanan Harapan Ibu Pekalongan, 2018.

[6] Kurniati, CH, "IbM Kader Aisyiyah Desa Karangnanas Dalam Pemberian ASI Ekslusif untuk Peningkatan Gizi pada Anak Stunting," Semnas LPPM UMP, ISBN: 978-602-6697-66-0, 2020.

[7] Heryana, "Etika Penelitian : Bahan Ajar Mata Kuliah Metodologi Penelitian Kuantitatif," Universitas Esa Unggul, 2020.

[8] Nasir, dkk, "Buku Ajar Metodologi Penelitian Kesehatan," Yogyakarta: Nuha Medika, Cetakan Pertama, 2011.

[9] Prasanti, "Perbedaan Produksi Asi Sebelum Dan Sesudah Pijat Oksitosin Dan Perawatan Payudara Pada Ibu Nifas Di Rsud Dr. R. Goeteng Tarunadibrata Purbalingga," Viva Medika, 2017.

[10] Pranajaya, R. \& Rudiyanti, Novita, "Determinan Produksi ASI Pada Ibu Menyusui," Jurnal Keperawatan, ISSN: 1907 - 0357, 2013.

[11] Putri \& Sumiyati, "Mengatasi Masalah Pengeluaran Asi Ibu Post Partum Dengan Pemijatan Oksitosin," Jurnal Keperawatan Soedirman (The Soedirman Journal of Nursing), 2015. 
[12] Sugiyono "Metode Penelitian Kuantitatif, Kualitatif, dan Kombinasi (Mixed Methods)," Bandung: CV. Alfabeta, 2014.

[13] Sugiyono, "Memahami Penelitian Kuantitatif," Bandung: CV. Alfabeta, 2013.

[14] Wahyuningsih, "Buku Ajar Kebidanan Asuhan Kebidanan Nifas dan Menyusui," Kementrian Kesehatan RI, Cetakan Pertama, 2018.

[15] Wijayanti \& Setiyaningsih, "Efektifitas Breast Care Post Partum Terhadap Produksi ASI," Jurnal Kebidanan, 2016.

[16] Yuniarti, "Metode Breast Care Meningkatkan Volume Asi Pada Ibu Nifas," Jurnal : Buletin Media Informasi Kesehatan, 2018. 